Ковтун, Альбіна. «Фразеотвірний потенціал релігійної лексики в сучасній комунікації». Лінгвостилістичні студії, вип. 10, 2019, с. 62-76.

Kovtun, Albina. "Religious Vocabulary in Modern Communication: Phraseology Formation Potential". Linguostylistic Studies, iss. 10, 2019, pp. 62-76.

Удк 811.161.2'373,23

https://doi.org/10.29038/2413-0923-2019-10-62-76

\title{
ФРАЗЕОТВІРНИЙ ПОТЕНЦІАЛ РЕЛІГІЙНОЇ ЛЕКСИКИ В СУЧАСНІЙ КОМУНІКАЦІЇ
}

\author{
Альбіна Ковтун \\ Чернівецький національний університет імені Юрія Федьковича, \\ Чернівці, Україна
}

У статті висвітлено фразеотвірні можливості релігійних фразеологізмів української мови (i тих, що не потребують декодування, і тих, які функціонують в узагальнено-образних значеннях). Ступінь відтворюваності мотивувальних ознак внутрішніх форм фразеологізмів із узагальнено-образним значенням висока. Аналітичним релігійним термінам, крилатим бібліїзмам, народним прислів'ям i приказкам, формулам мовного етикету і божби, власне фразеологізмам - усім фразеологічним одиницям, що містять релігійний компонент і видозмінені за формою чи за семантикою, притаманні підвищена експресія, образність, стилістична маркованість та оцінність.

Ключові слова: релігійна лексика, релігійна фразеологічна одиниця, трансформація / усічення / нарощення / компонентна заміна фразеологізму.

Kovtun Albina. Religious Vocabulary in Modern Communication: Phraseology Formation Potential. Lexical and grammatical changes in the phraseological unit structure with a religious element reflecting the Ukrainians' archaistic thinking is a continual process in the Ukrainian language. The flexibility of forms and interchangeability of the phraseological components is one of the reasons for the active use of such stable phrases in modern Ukrainian speech. However, the identification of the religious vocabulary potential in the phraseology formation system of modern Ukrainian against the traditional use of stable phrases with the religious component is still an understudied problem in the Ukrainian linguistics, which determined the choice of the topic for the research. The purpose of the article is to shed light on and contribute to better understanding of the formation potential of the phraseological units with religious lexemes. The analysis has been carried out using not only standard language dictionaries, dictionaries of biblical phraseological units, collections of proverbs and sayings, but also the samples of modern publicistic and artistic speech.

The case study of commonly used and occasional phraseological units with a religious component has revealed their semantic heterogeneity. On the one hand, these are the phraseological units that preserve the nominative meaning of its word-components and can be easily derived from their meanings without decoding. On the other hand, there are phraseological units with a new generalized figurative meaning created by blending the elements with direct meaning and the elements with figurative (metaphoric and metonymic) meanings. Blending of the two denotative (primary and secondary) situations determines the actual meaning of RFU, the basis of which is the internal form of a phraseological unit with a

(c) Ковтун А., Східноєвропейський національний університет імені Лесі Українки, 2019.

Це стаття відкритого доступу на умовах CC BY-NC 4.0 
religious component. The phraseological units resulting from the determination of the unknown through the well-known, associated with Christian traditions and the Bible, dominate in the Ukrainian language. Preservation of the internal forms of such stable units and the possibility of reproducing the motivation signs in them are high. The occasional word combinations with biblical elements, metaphorical and metonymic rethinking of the phraseological units with a religious context (proper phraseological units, stable analytical names of objects, phenomena and rituals from the religious life of Ukrainians, idiomatic expressions, proverbs and sayings) are especially vivid and expressive, full of associative imagery, stylistic originality and value. A great variety of such units points to significant productivity of the Ukrainian religious vocabulary and elucidates the importance of religion in the life of the Ukrainians.

Key words: religious vocabulary, religious phraseological unit, transformation / reduction/extension /component replacement of phraseological unit.

Вступ. Архаїчне мислення народу якнайкраще зберігають фразеологізми - душа кожної мови, віддзеркалення духу кожної нації. Релігійна лексика є однією з тих, що живить фразеологію української мови (Скрипник 49-51, 143).

Природний процес багатовікової історії української культури перервала доба комуністичного тоталітаризму - період розвитку без релігії, без національних святинь, без пам'яток культури християнського духу і традиції (Сулима 269). Як зауважив В. Німчук, «у державі з офіційною атеїстичною ідеологією, яка прагнула знищити віру в Бога, не могло бути й мови про використання багатющих покладів української лексики та фразеології, засвідченої в перекладах Св. Письма» (20), але оскільки релігійне слово в світогляді українців завжди займало чільне місце, укладачі словників радянського часу не могли зовсім ігнорувати релігійні фразеологічні одиниці (далі РФО) - «усталені, часто відтворювані в мовленні одиниці 3 високим рівнем образності, експресії, абстракції, символіки, узагальнення, 3 релігійною семантикою або релігійною конотацією та релігійними компонентами» (Куза 5). За даними В. Слонова, «Фразеологічний словник» 1966 р. (автор Н. Батюк) містить 24 бібліїзми, «Словник українських ідіом» 1968 р. (автор Г.Удовиченко) - 30, «Українсько-російський і російсько-український фразеологічний словник» 1971 р. (автор І. Олійник) - 84, «Словник української мови» 1970-1980 рр. (за ред. І. Білодіда) - 110 (Слонов). М. Скаб зауважила, що тоді перевагу надавали лексикалізованим РФО, які втратили первинну релігійну суть, набувши узагальнених, абстрактних значень. Наприклад, за Словником української мови, брати (взяти) гріх на душу - «робити що-небудь усупереч власній совісті, прийнятим нормам моралі» (Словник 2: 171), хоча в устах вірян це стійке словосполучення завжди зберігало первісний релігійний зміст (Скаб 108-109).

Із 2000-х рр. створено кілька українських словників біблійних фразеологізмів (А. Коваль, Ж. Колоїз та З.Бакум, Л.Будівська та 3. Сікорська). Характерною рисою сучасних неспеціалізованих тлумачних словників української мови є широке представлення РФО, які привертають 
увагу багатьох вітчизняних лінгвістів: наприклад, стійкі словосполучення з лексемами Бог, Богородищя, блаженний і благословенний, гріх і спокута та iн. аналізує Н. Бабич, групу Божих імен, розширених фраземами фольклорного походження, і складені терміни церковно-обрядової термінології - П. Мацьків, вигукові (етикетні, емоційно-виражальні, магічні) одиниці - Г. Кузь, обрядові, що зберігають архетипні релігійні уявлення, - В. Васильченко, церковно-обрядові Полісся та Східної Слобожанщини - І. Царьова, біблійні в українській мемуаристиці поч. XX ст. - Л. Ткач та I. Шепетюк, біблійні в українській художній літературі С. Богдан, Ж. Колоїз, М. В. Скаб, М. С. Скаб, О. Ципердюк, біблійні онімні В. Денисюк та ін. Комплексний аналіз особливостей функціонування українських релігійних фразеологізмів здійснила А. Куза, схарактеризувавши за українськими лексикографічними працями генетичні, структурно-семантичні, тематичні групи релігійної фраземіки й окресливши ії̈ роль в публіцистичних творах Є. Сверстюка, проповідях С. Шевчука та в інтернет-просторі. При цьому лексичне і граматичне оновлення структур РФО в сучасній українській мові залишається мовознавчою проблемою, що зумовлено мобільністю форм РФО - постійного джерела експресивності, основної причини їх актуалізації в сучасному мовленні, на думку В. Мокієнка (26).

Мета дослідження - виявлення фразеотвірного потенціалу релігійної лексики в сучасній українській мові на тлі традиційного використання РФО, зокрема систематизація особливостей їх видозміни.

Матеріал і методи дослідження. Аналіз здійснюємо 3 позиції широкого розуміння фразеологізму, зіставляючи кодифіковані одиниці, вміщені в загальномовних, фразеологічних словниках, зібраннях біблійних крилатих висловів, прислів"їв та приказок, із актуалізаціями в художніх та публіцистичних текстах сучасної української мови. Для з'ясування семантичних структур опорних лексем РФО застосовано метод компонентного аналізу; релевантність значень РФО в сучасному мовленні уточнено за допомогою контекстного аналізу; для визначення місця релігійної фразеології в українських лексикографічних працях і типології РФО залучено метод лексикографічного опису.

Результати дослідження та дискусія. В українській мові функціонує група РФО, які не потребують декодування, оскільки їх значення прямо випливають із семантики слів-компонентів, а закріплення стабільності складу компонентів таких одиниць відбулося завдяки їх активному повторенню у процесі номінування. Такими РФО є стійкі аналітичні термінні назви предметів та явищ релігійного життя українців (Великодній тиждень, Свята вечеря, Святі місия, класти на себе хрест ('хреститися')), крилаті біблійні одиниці (смертний гріх (Мр. 3: 29); таємна вечеря (Мр. 14: 12-25); Не судіть, щоб і вас не судили (Мт. 7: 1); Хто має вуха, нехай слухає (Мт. 13: 16)), народні прислів'я і приказки (Хто рано встає, тому Бог дає (Українські приказки 49); Мовчи, глуха, менше гріха 
(Українські приказки 90); Холодно, наче перед Різдвом (Украӥнські приказки 68)) та лексикалізовані формули мовного етикету і божби, хоча чимало 3 промовлених вірянином сприймаються й нині як вільні словосполучення (Христос воскрес! Богу дякувати! Бог на поміч! Боже борони! Не гніви Бога! Христом-богом молю! Бог мені свідок! Побий мене святий хрест! Чорт його бери! Сто дідьків йому в голову!).

Звісно, будь-який фразеологізм, «потрапивши в авторський текст, передає останньому ту енергію, що вироблена і закріплена в ньому протягом тривалого функціонування в народному побуті, у сфері виробничій, культурно-науковій тощо» (Мойсієнко 115), проте мовці вносять до відомих фразеологічних конструкцій потрібні емоційносмислові та стилістичні корективи, наприклад, замінюючи певний компонент синонімом: мати страх на душі 'бути в стані хвилювання, тривоги, неспокою’ (Словник (Білодід) 9: 753; Словник (Русанівський)) $\rightarrow$ Озирнися! / Глянь-бо: небо падає... / Хоч здригнись! / Впусти у душу ляк... (Т. Севернюк) (покликаючись на художні тексти, зазначатимемо лише автора - А. К.); душа вилітає з тіла «хто-небудь помирає, гине» (Фразеологічний словник 226) $\rightarrow$ Він чує в грудях вже палючі спеки, / вже посіріли дні й верхів яса. / І відійде душа за грунь далекий, / і відійде душа у небеса (В. Вознюк); відійти у царство небесне / небуття / вічність / довічний сон / Божу (останню) путь (дорогу) 'померти' (Словник (Русанівський)) $\rightarrow$ Він відійшов у небеса, пам'ятайте про нього, друзі («Гетьман», 2017, № 38) (покликаючись на публіцистичні тексти, зазначатимемо назву видання, рік та номер - А. К.). Ступінь експресивності вторинних РФО завжди вищий. Порівн.: Cmpax Господній - криниця життя, щоб віддалятися від пасток смерти (С. Процюк) $\rightarrow$ Я ж і не відаю, Боже, й не знаю - / Мужність гріховна чи боязнь Господня уперта? (М. Лазарук).

Значно більше, за нашими спостереженнями, тих РФО, які виникають унаслідок визначення чогось невідомого через відоме, пов'язане 3 християнськими традиціями та біблійними подіями, на чому мовець вибудовує інший, уже нерелігійний, семантичний план - нове узагальнено-образне значення за допомогою порівняння, метафори та метонімії.

1. Порівняння. Поряд із відомими прислів'ями i приказками, побудованими за допомогою порівняння (бідний, як церковна миша; голо, як у турецькій церкві; ясно як Божий день; дивиться, як піп на ризи; допоможе, як мертвому кадило; неначе з хреста знятий; крутить, як чорт греблею; прибратись, як на Великдень), сформовано низку порівнянь із компонентами-бібліїзмами: Мало у нас уяви, ми, як невірний Хома, віримо тільки в ті рани, в які вкладаємо наші персти (Леся Українка); Потерчатами / Думки, безвірні, як Хома. / То крають спогади на териії, / То викорчовують слова (І. Людвенко); Він тепер як блудний син, і раптом йому така увага (Іван Ле); А що, якби знайшлася хоч одна (книга. - А.К.) - $в$ 
монастирі десь або на горищі? Якби вціліла в тому пожарищі - неопалима наче купина? (Л. Костенко); Схильність XVII cm. до різнорівневого синтезу дозволяє розглядати його як альфу і омегу (а точніше - омегу і альфу) історії західноєвропейської культури (А. Скакун).

2. Метафора. Перенесенням за подібністю утворено чимало незмінних стійких аналітичних термінних назв предметів та явищ релігійного життя українців, що грунтуються на християнському сприйнятті подібностей ново- i старозавітного, християнського й нехристиянського, релігійного та нерелігійного: струї (джерела) 'стрічки, якими обшита архиєрейська мантія' (Пуряєва 126) - стрічки на мантії - як струї (джерела), Агнець Божий 'Ісус Христос' (Словник (Русанівський)) Ісус Христос - як старозавітний жертовний баранець, Божий (Господній) дім 'храм' (Словник (Русанівський)) - за язичництва храм розуміли як справжній дім бога, а із «запровадженням християнства ці вирази поступово звільнилися від конкретності, ставши метафоричними» (Піддубна 11)).

Поза релігійною сферою частина таких найменувань зазнала подальшого метафорного розвитку. Так, стійким термінним словослученням одним миром мазані, що первісно означало 'однієї віри', іронійно називають осіб, дуже схожих між собою в чому-небудь (перев. негативному) (Фразеологічний словник 363); Агнець Божий - поряд зі значенням 'Ісус Христос' - номінує покірливу, розумово обмежену людину (Фразеологічний словник 9); паралельно з прямим використанням божа пташка (саме так, за легендою, називають, зокрема, ластівку, створену Богом із землі) кодифіковано значення 'безтурботна людина' (Фразеологічний словник 583); стійкі назви-словосполуки церковних обрядодій читати проповідь, читати молитву набули секулярних значень 'повчати кого-небудь' (Фразеологічний словник 765), 'дорікати кому-небудь, лаяти, сварити когось' (Фразеологічний словник 764). За нашими спостереженнями, в українському мовленні XX - XXI ст. набагато більше, ніж словникових, таких семантичних дериватів: Не знав комбат, з чого почати, як відпускати гріх цьому клятому Діденкові... (О. Гончар); Та не дітей же тобі з ним хрестити? - дорікає собі в думці Богдан (О. Гончар); А Судді хто? Американці. Англійці. Хрещені батьки підсудних і до якоїсь міри учні (О. Довженко); <...> до Віри потихеньку вступив Ганс та почав свій акафбіст. Що вони, мовляв, думають? (У. Самчук); За подальші кілька тижнів курс на асоціацію з ЄС було демонстративно згорнуто, перетворившись до 21 листопада, коли було ухвалено рішення про призупинення підготовчих робіт до підписання угоди, на «символ віри», на точку покладання надій як мінімум половини української нації, зокрема, майже всього молодого покоління України («День», 2013, №239); Світляний стовп зник. Нічого не боліло, мовби став невразливим... Аж на старість звершилося його небесне миропомазання («Українська літературна газета», 2012, № 7) та ін. Відтінки іронійності й комічності - одна 3 
яскравих рис метафорно-фразеологічних відтермінних похідних.

Мовці, переносячи біблійну конкретику крилатих висловів у повсякденне життя, розширюють сенси одиниць Святого Письма. Серед таких РФО розрізняємо слова узагальнено-метафорного походження, наслідуючи Л. Скрипник (Скрипник 98) (Едем, Голгофа, Мекка, Каїн, Ірод, Iуда, Понтій Пілат та ін.); словосполучення (вогненний стовп, вдовина лепта, вавилонська башта, тридиять срібників, повернення блудного сина, першим кинути каменем, розсипати перли перед свинями), що стилістично належать до книжної фразеології та містять у своєму складі чимало одиниць, скалькованих зі старослов'янської мови (золотий тілець, камінь спотикання, сіль землі, терновий вінок, Хома невірний) (Ужченко 154); крилаті речення (Хто яму копає, той в неї впаде; Хіба реве віл, коли ясла повні?). Біблійні одиниці зберігають давню народну мудрість та історію людства: свій (важкий, тяжкий хрест) 'терпляче зносити всі труднощі' (Фразеологічний словник 433) пов'язане зі стародавнім звичаєм нести хрест до місця своєї страти, що випало на долю й Ісусові Хресту.

Саме група бібліїзмів найбільше потрапляє під вплив трансформування. Найуживаніші 3 них осучаснюють свої форми синонімами: Поцілунок іуди 'вчинок людини, що прикриває облесливістю свою зраду, свої ниці помисли’ (Коваль 218) $\rightarrow$ Ти уважно розглядаєш / Рубець від поцілунку учня / Що червоніє на його неголеній щоці / Мов слід тупого леза (С. Жадан) - гіперонімом учень підкреслено невдячність за передані знання Учителем. Тридиять срібняків 'грошова винагорода за зраду' (Фразеологічний словник 719) - Левам знову милять гриви, / Аж не милий левам світ, / і за тридиять, але гривень / продають тут пустоцвіт (М. Лазарук) - поет пропонує гривень замість срібняків, щоб нагадати сучасникам повчальну біблійну історію.

Можливим $€$ оновлення біблійних фразеологізмів за допомогою антонімів: нести свій (важкий, тяжкий) хрест 'терпляче зносити труднощі' (Фразеологічний словник 433) $\rightarrow$ Чому я волочу свій хрест, як борону за собою? (В. Вовк) - заміною компонента несу контекстним синонімом волочу акцентовано на ноші, часто непомірній для людини; Оŭ, не важко / Переступити камінь на дорозі, - / Та як же / Обійти свій хрест, / Коли з пробитої долоні / В пилюку / Й досі крапле кров... (С. Жолоб) замість компонента нести автор використовує компонент обійти контекстний антонім, що відтворює протилежну ситуацію до смирення Богові; Я несла за Тобою непомітний хрест, / Не той дубовий, з раменами широкими, як кладка, / А легкий, ясеновий, ще зелений. / Втомилася (В.Вовк) - антонім непомітний замінив компонент важкий, що перетворило значення РФО, пов'язане з неминучими проблемами у житті людини, на 'іти життєвим шляхом (за долею)'.

Синтаксичне оновлення бібліїзмів передбачає також усічення i нарощення крилатих словосполук. Стягнення структури бібліїзмів до домінантного компонента сприяє акумуляції образно-смислової 
інтенсивності, а також реалізації принципу економії, притаманного всім одиницям мови. Cyєma cyєm 'те, що позбавлене будь-якого значення, вартості' (Фразеологічний словник 701) $\rightarrow$ суєта: Не усім там, певно, вже мажорно / Втримати для себе висоту - / Автострада унизу, мов жорна, / Крутить й крутить віку суєту (В. Вознюк); Може, й справді / Смерть - то єдине вивільнення / І щось набагато вище, / Ніж оце мирське перебування / У суєті суєт і вічній суєті (Т. Севернюк); Пресовані суєт щоденним пресом / I молимось, i зводим свій Парнас (В. Вознюк). Терновий вінок 'муки, страждання' (Фразеологічний словник 110) $\rightarrow$ вінок: Бог сплів тобі вінок, як Синові своєму:/ Тернину білоцвітну, що глибоко коле, / Щоб сходили криваві суниці на зубах... (В.Вовк). неопалима купина (кущ) 'стійкість, незнищенність' (Коваль 61) $\rightarrow$ кущ: Не твої фонтани моляться / Нa чотках краплин, / Не пелюстки твоїх магнолій / Обсипаються в травні під «Радуйся», / Не горять квітники в півоніях / Кущем, де з'явився Мойсею Великий (В. Вовк). Содом і гоморра 'велике безладдя, хаос; беззаконня (за біблійною оповіддю, від назв палестинських міст, знищених Богом за розпусту їхніх мешканців)' (Словник (Жайворонок) 1072) $\rightarrow$ содом або гоморра: / В цім гонорі, у цій гоморрі, / В цім гаморі, неначе в морі - Я Як ми почути трубний глас? / Як він спасти нещасних нас? (О. Ірванець); Не в Хохломі, не в Оклахомі,/ У цій осаді, в цій судомі, / У цім содомі, в цім диму / Що ми порадити кому (О. Ірванець); Відплачте мене в суботу / Червоним чи білим вином. / А поки живуя - доти / Грабуйте медові соти: / Там пекло і тут содом (М. Матіос); Хто ти є, коли довкіл содом? / Які безумні дні й безумні люди? / В час, коли все пішло на лом, / Хто пришпилить квіточку на груди? (М. Матіос). Юдині срібняки / срібляки (тридиять срібняків) «винагорода за зраду» (Фразеологічний словник 686) $\rightarrow$ срібняки: <..> ганьби иурався, мов смоли. / Підступної, чужинської тієї, / Що зрадою іудиною звуть, / За срібляки, карбованці чи леї / Затягують в багатства каламуть (В. Вознюк). Всесвітній потоп 'величезна катастрофа, стихійне лихо' (Коваль 32) $\rightarrow$ nomon: Я думав, кожен проживав ті дні, / Немов останній день перед потопом (М. Лазарук).

Наповнення крилатих слів і словосполук додатковими лексичними компонентами надають дериватам тематичної чи соціальної спрямованості. Содом і гоморра $\rightarrow$ Мікро-Содом, зашторена Гоморра, / просніться, люди, чуєте, біда! (Л. Костенко) - замість повторення відомого бібліїзму содом $i$ гоморра, Л. Костенко окреслює ще й на масштаб описуваного. Мойсей «пророк, визволитель, чудодій, проповідник» (Коваль 79) $\rightarrow$ Убили землю! Вибили з-під ніг! / I в зашморгу забилась Україна. / Не виведе новітній нас Мойсей / На інші зорі й тихі води (І. Жиленко) додання компонента новітній кардинально змінило зміст бібліїзму Мойсей (надійний рятівник $\rightarrow$ ненадійний лідер). Царство небесне (вічне, Боже, Господне) $\rightarrow$ Грім / Паде в потоки - вірить тільки водам, / Бо Царством задихається Господнім (В. Герасим'юк) - якщо первісно Царство небесне 
означало 'місце, де блаженствують', то в цьому поетичному контексті - це 'місце з несприятливими умовами перебування'.

Ще однією особливістю є оновлення морфологічного рівня бібліїзмів: наприклад, заміна однини на множину (Йов 'людина, яка зазнала багато горя і злигоднів' (Коваль 102) $\rightarrow$ I ми лишилися ні в сих, ні в тих, / як два старенькі Йови в ніч осінню (І. Жиленко); Іуда (Юда, Iуда Iскаріот) 'зрадник, лицемір, людина продажної душі' (Коваль 213) $\rightarrow$ Є поруч люди. $\epsilon$ іуди (В. Вознюк); Це ж бо спільна перемога, / Але ж кожному своє: / Левам шиї наставляти, / Юдам брати срібляки (М.Лазарук)); заміна прикметника на іменник + прийменник (терновий вінок 'символ страждання' (Коваль 225) $\rightarrow$ Ходять іще по землі / Ti, що замовили в тридцять / Хрест, і Голгофу, i глід, / I з терену вінок, а не з глиці (М. Лазарук)).

Спостережено трансформації біблї̈змів змішаного типу. Манна небесна 'несподівано отримані життєві блага' (Коваль 64) $\rightarrow$ На цій землі було вже їм бувальців, / Тут Бог не сіяв з неба їм крупу (Л. Костенко) відбулася синонімійна заміна компонентів (манна $\rightarrow$ гіперонім круna) та морфологічне оновлення (небесна $\rightarrow$ неба). Манна з неба (з небес) падає 'що-небудь дістається дуже легко, без особливих зусиль' (Фразеологічний словник 367) $\rightarrow$ Виходьте, люди, в Ніч Різдвяну. / Туди, куди веде Звізда. / Зійде на Київ біла манна, / А на людину - благодать (І. Жиленко) - усічено компонент з неба (з небес), замінено компонент впаде (про манну небесну) синонімом зійде під впливом сюжету про схід першої різдвяної зірки. Лавровий вінок 'слава, почесті' (Фразеологічний словник 110), терновий вінок 'муки, страждання' (Фразеологічний словник 110) $\rightarrow$ Ота, що схід, / хоч надто зримий - захід, / Де сниво дня у видивах безсонь, / I на чолі натомленої птахи - / Вінець лавровий з тернових долонь... (Т. Севернюк) контаміноване поєднання лавровий вінок і терновий вінок, «сигналом» до чого стало слово вінок (лавровий і терновий); бібліїзм терновий вінок вступив у метафорний зв'язок із фразеологізмом лавровий вінок, видозмінився в тернові долоні, перебравши «на себе роль трансляторів асоціативної інтенції» (Мойсієнко 118).

Народні прислів'я та приказки з релігійною лексемою у своєму складі, як і всі інші прислів'я та приказки, - це висловлення, прямі (за О. Потебнею, найближчі) значення яких у процесі переходу в прислів'я стають постійними поясненнями до змінюваних пояснюваних, тобто алегорійними, як алегорії в байках (Потебня 55): не все коту масниця значення 'жарт. закінчилося для когось безтурботне життя' (Фразеологічний словник 368) утворене через переосмислення предметної співвіднесеності вільносинтаксичного прототипу фраземи, внутрішня форма якої містить мотиваційну ознаку. Формування таких прислів'їв та приказок відбувається завдяки залученню назв релігійних свят, обрядів, ритуалів (Прирівняла Божсий дар (тобто щось значуще, цінне) до галушок (тобто до дріб'язку) (Українські приказки 540); Чекай ряду, дістанеш 
коляду ( $\rightarrow$ нагороду) (Украӥнські приказки 265); Чужа ласка сироті Великдень (Українські приказки 474) - 'радість'; Яка сповідь, таке й розгрішення ( $\rightarrow$ 'вклад', 'результат') (Українські приказки 326); Що попові можна, то дякові зась ( $\rightarrow$ 'хтось авторитетний', 'хтось малодосвідчений') (Українські приказки 86)); часто такі фольклорні одиниці слугують іронійній характеристиці людини, зневажання (попівські очі (Українські приказки 236) - про заздрісного; Де храм, и я тамъ (Українські приказки 301) - про нерозважливого; чортове насіння (Українські приказки 387) про поганого нащадка; Покаявся злодій у ягодах (Українські приказки 134) про кого-небудь невиправного; могти відрізнити Божий дар від яєчні (Фразеологічний словник 106) - про чиюсь нерозбірливість.

Іронійності досягають, утворюючи метафорні РФО від відомих нерелігійних фразем, додаючи до них релігійні компоненти, для порівн.: «По коліна; в коліно. «1. чого. Багато. У хаті райно-багно, сміття по коліно (Панас Мирний); Снігу насипало в коліно (I. Франко). 2. Глибоко. - Місце me, де стояли (економії), в коліно зоремо (С. Васильченко)» (Фразеологічний словник 305) - Мудрий дід, та по коліна в біблії, - сказав я, коли надокучило його слухати (Р. Андріяшик), тобто 'занадто богомільний” - це приклад мовленнєвого «розкріпачення внутрішньої форми і оживлення образності фразеологізмів» (Телия 24).

3. Метонімія. Фразеологізми метонімійного походження містять об’єктивну, чітку інформацію, здебільшого легко декодовані та, як підказує фактичний матеріал, стійкі до трансформацій: від Адама «дуже здалека, з самого початку» (Фразеологічний словник 19), від потопу «з сивої давнини, з давніх-давен» (Фразеологічний словник 550).

Групу метонімійних РФО наповнюють: 1) власне фразеологізми (зокрема, із соматизмами: дай / давай Боже (Бог) ноги 'уживається для вираження необхідності раптової втечі звідкись' (Фразеологічний словник 186); богу у вуха 'щоб здійснилося що-небудь' (Фразеологічний словник 140); мати Бога в серці (в душі, в животі) 'бути милосердним, добрим, совісним, справедливим і т. ін.' (Фразеологічний словник 372); не мати Бога в серці (в душі, в животі) 'бути жорстоким, бездушним, несправедливим і т. ін.' (Фразеологічний словник 379); адамове ребро / реберце 'жарт. - про жінку' (Словник (Білодід) 1: 19); адамова голова 'зображення черепа зі схрещеними кістками, що лежить під ними (символ смерті)' (Словник (Жайворонок) 16)); 2) стійкі аналітичні термінні назви предметів та явищ релігійного життя українців (наприклад, часова модель «пам'ятна релігійна подія $\rightarrow$ релігійне свято на честь цієї події»: Воскресіння Христове 'Великдень' (Словник (Жайворонок) 165); синекдохічна модель 'частина (елемент обрядодії) $\rightarrow$ ціле (релігійна обрядодія)': іти (nimu, постригатися, постригтися) в ченці 'ставати ченцем, іти в монастир' (Словник (Білодід) 11:311), вводити (ввести) у віру (в хрест) 'заст. Здійснювати обряд хрещення; хрестити' (Словник (Білодід) 11: 139), держати до хреста дитину 'бути хрещеним батьком або хрещеною 
матір'ю' (Великий тлумачний словник 1572), запечатувати гріб 'здійснювати обряд печатання гробу, роблячи лопатою знак хреста над кожним боком могили' (Пуряєва 55); виведення (вивід) молодої, винесення плащаниці, класти поклони, поклоніння хресту, намащення хворих, піднесення Святих Дарів, піднесення святого Агния, ламання святого Агния та ін. (Осінчук 161-175)); 3) бібліїзми: Всевидюще (Всевидяче, Всевидяще) Око 'про Бога' (Словник (Жайворонок) 169) та ін.

РФО метонімійного походження іноді піддаються семантикостилістичному (передусім адгерентному) оновленню. Для порівн.: $A$ mu, всевидящеє око! / Чи ти дивилося звисока, / Як сотнями в кайдани гнали / В Сибір невольників святих... (Т. Шевченко) - 'ірон. про Бога'; - Лавриненко, не відставати! Не відставати! - Всевидящеє око двадиятирічного командира слідкувало за всіма розрахунками (М. Стельмах) - 'ірон. про прискіпливого командира'; вовк в овечій шкурі 'лицемірна людина, яка під маскою доброчинності приховує злі наміри' (Фразеологічний словник 119) $\rightarrow$ Може, ці сиворунні слова / Тільки шкура овеча? (І. Римарук) - 'прикриття'.

Окрім видозміни компонентного складу, метонімійні РФО мають здатність згодом метафоризуватися, відкидаючи «належність об'єкта до того класу, до якого він насправді входить», і стверджуючи «його залучення до категорії, в яку він не може бути віднесений раціонально» (Арутюнова 17). Так, від людська душа в метонімійному значенні 'людина' (Кожна душа не з лопуцька, того ж хоче, що й людська (Марко Вовчок)) розвинулася низка метафорних РФО із метонімійним компонентом душа: заяча душа 'боязка, полохлива людина' (Фразеологічний словник 228): мишача душа 'боязка, полохлива людина з дріб'язковою, підлою вдачею' (Фразеологічний словник 229); чорнильна душа 'хто-небудь обмежений у своїй діяльності вузькими службовими обов'язками, інтересами; бюрократ, канцелярист' (Фразеологічний словник 229). У Фразеологічному словнику української мови, за підрахунками М. В. Скаб, зафіксовано 23 такі одиниці в метафорному значенні «сукупність рис, якостей людини»: відкрита душа, щира душа, каїнова душа, канцелярська душа, мотузяна душа, порожня душа, пропаща душа, розхристана душа, хвацька душа, хвора душа, широка душа, окаянна душа та ін.

Зауважимо, що кількісна перевага прозорих внутрішніх форм РФО не викликає сумніву («у фразеологічній системі української мови, як і в інших слов'янських, переважають фразеологічні одиниці із мотивованою внутрішньою формою» (Івченко 90)), однак можна натрапити і на ФРО 3 невивідною основою: адамова голова 'ент. - великий нічний метелик 3 родини сфінксів' (Словник (Білодід) 1:19), 'жовті зозульки, черевички (рослина)' (Жайворонок 9). Визначити походження немотивованих РФО складно через наявність кількох версій про утворення таких фразеологічних зрощень, тому О.Селіванова називає ці одиниці псевдомотивованими (Селіванова 46). Наприклад, відомо кілька припущень щодо утворення фразеологізму підвести / підводити під монастир 'кого і без додатка. 
Обдуривши, накликати біду, поставити кого-небудь в скрутне або незручне становище' (Фразеологічний словник 631): 1) підводили сліпого під монастир, аби позбутись клопоту (стіна монастирська довга); 2) підводили ворога під стіни монастиря, що на час війни виконувала функцію фортеці; 3) підводили грішника під монастир, залишаючи його там для смирення на певний час (Огієнко 54-55). Кожна з версій указує на існування зв'язку внутрішньої форми цього фразеологізму та його усічених компонентів: підвести сліпого під монастир, підвести ворога під монастир, підвести грішника під монастир та ін. Із погляду суб'єкта дії сліпий, ворог, грішник є постраждалими, а монастир - місце зосередження їх негараздів: для ворога монастир - це проблема, тому що $є$ архітектурним комплексом, споруджуваним у вузлових місцях, територію якого обносили високою неперервною кам'яною стіною та кутовими вежами, пристосовуючи до оборони від нападників; для людини, яка згрішила, монастир - це місце суворого режиму, що вимагає обмежень від членів чернечої громади, які «ведуть невпинну боротьбу з своїм тілом і всіма способами допомагають перемозі духа» (Огієнко 54-55), i т. ін. Відновлення образу розтлумачує реальне значення РФО: потай підвести кого-небудь під стіни монастиря, створивши йому проблеми (в прямому значенні) $\rightarrow$ діями, словами чи обманом поставити кого-небудь у скрутне або незручне становище; обдурити (в образному).

Висновки та перспективи дослідження. Семантичну неоднорідність РФО забезпечують одиниці двох типів: РФО зі збереженням прямих значень, що випливають із суми значень слівкомпонентів та не потребуючи декодування, і РФО із новоутвореними узагальнено-образними значеннями. Накладання двох денотативних (первинної та вторинної) ситуацій формує актуальне значення РФО, основою якого $\epsilon$ внутрішня форма РФО. Ступінь відтворюваності мотивувальних ознак внутрішніх форм фразеологізмів із узагальненообразним значенням висока. І метафорним, й метонімійним похідним РФО (аналітичним термінним назвам предметів та явищ релігійного життя українців, крилатим біблійним одиницям, народним прислів'ям і приказкам, формулам мовного етикету і божби, власне фразеологізмам) притаманні підвищена експресія, асоціативна образність, стилістична маркованість та оцінність. Широка мовленнєва варіантність РФО свідчить про їхню стабільність функціонування і важливу роль релігії в житті українців. Перспективним напрямом подальших лінгвістичних студій видається з'ясування специфіки функціонування релігійної фразеології в сучасних інформаційних засобах, зокрема в соціальних мережах.

\section{Список використаних джерел}

Великий тлумачний словник сучасної української мови, за ред. В. Т. Бусла. Київ; Ірпінь: ВТФ «Перун», 2007. 
Жайворонок, Віталій. Знаки української етнокультури: словник-довідник. Київ: Довіра, 2006.

Коваль, Алла. Спочатку було Слово: крилаті вислови біблійного походження в українській мові. Київ: Либідь, 2001.

Словник української мови, за ред. В. В. Жайворонка. Київ: Видавничий центр «Просвіта», 2012.

Словник української мови, за ред. І. К. Білодіда. В 11 т. Київ: Наукова думка, 1970-1980.

Словник української мови, за ред. В. М Русанівського. В 20 т. Київ: Наукова думка, 2010-2018.

Пуряєва, Наталія. Словник церковно-обрядової термінології. Львів: Видавничий відділ «Свічадо» Монастиря Монахів Студитського Уставу, 2001.

Українські приказки, прислів'я і таке інше, укл. М. Номис. Київ: Либідь, 1993.

Фразеологічний словник украйнської мови, укл. В. М. Білоноженко, В. О. Винник, I. С. Гнатюк та ін. У 2 кн. 2-ге вид. Київ: Наукова думка, 1999.

\section{Sources}

Velykyi tlumachnyi slovnyk suchasnoi ukrainskoi movy, edited by V. T. Busel. Kyiv; Irpin: VTF "Perun", 2007.

Zhaivoronok, Vitalii. Znaky ukrainskoi etnokultury: slovnyk dovidnyk. Kyiv: Dovira, 2006.

Koval, Alla. Spochatku bulo Slovo: krylati vyslovy bibliinoho pokhodzhennia v ukrainskii movi. Kyiv: Lybid, 2001.

Slovnyk ukrainskoi movy, edited by V. V. Zhaivoronok. Kyiv: Vydavnychyi tsentr "Prosvita", 2012.

Slovnyk ukrainskoi movy, edited by I. K. Bilodid. 11 vols. Kyiv: Naukova dumka, 1970-1980.

Slovnyk ukrainskoi movy, edited by V. M Rusanivskyi. 20 vols. Kyiv: Naukova dumka, 2010-2018.

Puriaieva, Nataliia. Slovnyk tserkovno-obriadovoi terminolohii. Lviv: Vydavnychyi viddil "Svichado" Monastyria Monakhiv Studytskoho Ustavu, 2001.

Ukrainski prykazky, pryslivia i take inshe, edited by M. Nomys. Kyiv: Lybid, 1993.

Frazeolohichnyi slovnyk ukrainskoi movy, edited by V. M. Bilonozhenko, V. 0. Vynnyk, I. S. Hnatiuk et al. 2 vols. $2^{\text {nd }}$ ed. Kyiv: Naukova dumka, 1999.

\section{Список використаної літератури}

Арутюнова, Нина. Метафора и дискурс. Москва: Прогресс, 1990.

Бабич, Надія. Богословський стиль украӥнської мови у контексті стилістичної науки. Чернівці: Букрек, 2009.

Богдан, Світлана. «Біблеїзми в системі епістолярного автопортретування Лесі Українки». Волинь філологічна: текст і контекст, вип. 17, 2014, с. 15-36.

Васильченко, В'ячеслав. «Відображення українськими обрядовими фразеологізмами статусної зміни зовнішності людини». Українська мова, № 1, 2010, с. 67-81.

Денисюк, Василь. «Варіантність фразеологічних одиниць (на матеріалі східнослов'янської середньовічної історіографії)». Науковий вісник Криворізького державного педагогічного університету: Філологічні студії, вип. 16, 2017, с. 87-95.

Івченко, Анатолій. Українська народна фразеологія: ареали, етимологія. Харків, 1996.

Колоїз, Жанна. «Біблійна алюзія як засіб вираження авторської інтенції в романі В. Шкляра «Залишенець. Чорний Ворон»». Науковий вісник Чернівещького національного університету: Романо-слов'янський дискурс, вип. 659, 2013, с. 3-9.

Куза, Анжела. Українська релігійна фразеологія: особливості функціонування в сучасному мовному просторі. Автореф. дис. ... канд. філол. наук: 10.02.01. Львів, 2016. 
Кузь, Г. «Вплив християнського світогляду на компонентний склад та функції вигукових фразеологізмів». Біблія і культура, вип. 1, 2000, с. 233-7.

Мацьків, Петро. Концептосфера Бог в українському мовному просторі. Київ - Дрогобич: Коло, 2007.

Мойсієнко, Анатолій. «Актуалізація фразеологічних одиниць у художньому тексті». Українська лексикографія в загальнослов'янському контексті: теорія, практика, типологія: матеріали Міжнародної наукової конференції, присвяченої пам'яті проф. Л. Г. Скрипник. Київ: Видавничий дім Дмитра Бураго, 2011, с. 115-21.

Мокиенко, Валерий. Славянская фразеология. Москва: Высшая школа, 1989.

Німчук, Василь. «Християнство й українська мова». Українська мова, № 1, 2001. с. 11-30. Огієнко, Іван. Українське монашество. Київ: Наша культура, 2002.

Осінчук, Юрій. Історія української богослужбово-обрядової лексики. Київ: Видавничий дім Дмитра Бураго, 2009.

Піддубна, Наталія. Формування номенклатури назв релігійних споруд в українській мові: автореф. дис. ... канд. філол. наук: 10.02.01. Харків, 2000.

Потебня, Олександр. Из лекций по теории словесности. Басня. Пословица. Поговорка. Харьков: Госиздат Украины, 1930.

Селіванова, Олена. Нариси 3 української фразеології (психолінгвістичний та етнокультурний аспекти). Київ - Черкаси: Брама, 2004.

Скаб, Марія, Скаб, Мар'ян. «Біблійні фразеологізми як об'єкт мовної гри в сучасній українській літературі». Ученые записки Таврического национального университета им. В. И. Вернадского. Серия: Филология. Социальные коммуникации, т. 25 (64), № 2 (1), 2012, с. 232-7.

Скаб, Марія. «Фразеологізми з релігійним компонентом в українських словниках». Українська лексикографія в загальнослов'янському контексті: теорія, практика, типологія: матеріали Міжнародної наукової конференції, присвяченої пам'яті проф. Л. Г. Скрипник. Київ: Видавничий дім Дмитра Бураго, 2011, с. 107-14.

Скрипник, Лариса. Фразеологія української мови. Київ: Наукова думка, 1973.

Слонов В. «Біблія на уроках української мови». Урок української, № 2, 2002, с. 37-42.

Сулима, Віра. Біблія і українська література. Київ: Освіта, 1998.

Телия, Вероника. Типы языковых значений. Связанное значение слова в языке. Москва: Наука, 1981.

Ткач, Л., Шепетюк, І. «Євангелійні мотиви в українській народній фразеології та в дискурсі української мемуаристики початку XX ст. (за щоденниками С. Єфремова)». Науковий вісник Чернівецького національного університету: Слов'янська філологія, вип. 87, 2000, с. 109-127.

Ужченко, Віктор, Ужченко, Дмитро. Фразеологія сучасної української мови. Київ: Знання, 2007.

Царьова, Ірина. «Обрядофраземи північноукраїнських і східнослобожанських говірок». Волинь-Житомирщина, № 22(II), 2010, с. 289-95.

Ципердюк, Оксана. «Біблійні алюзії в поетичних текстах Василя Герасим’юка». Науковий вісник Чернівецького національного університету: Романо-слов'янський дискурс, вип. 772, 2016, с. 110-5.

\section{References}

Arutjunova, Nina. Metafora i diskurs. Moskva: Progress, 1990.

Babych, Nadiia. Bohoslovskyi styl ukrainskoi movy u konteksti stylistychnoi nauky. Chernivtsi: Bukrek, 2009.

Bohdan, Svitlana. "Biblical Exspressions in a System of an Epistolary Selfportrait of Lesia Ukrainka". Volyn filolohichna: tekst $i$ kontekst, iss. 17, 2014, pp. 15-36. 
Vasylchenko, Vyacheslav. “Status Changing of Human's Exterior and Its Reflection by Ukrainian Ceremonial Phraseological Units". Ukrainska mova, no 1, 2010, pp. 67-81.

Denysiuk, Vasyl. "Dimorphism of phrazeological units (on the materials of east-Slavic medieval historiography)". Philological Studies. Scientific bulletin of Kryvyi Rih State Pedagogical University, iss. 16, 2017, pp. 87-95.

Ivchenko, Anatolii. Ukrainska narodna frazeolohiia: arealy, etymolohiia. Kharkiv, 1996.

Koloiz, Zhanna. "Bibliina aliuziia yak zasib vyrazhennia avtorskoi intentsii v romani V. Shkliara "Zalyshenets. Chornyi Voron"”. Naukovyi visnyk Chernivetskoho natsionalnoho universytetu: Romano-slovianskyi dyskurs, iss. 659, 2013, pp. 3-9.

Kuza, Anzhela. Ukrainska relihiina frazeolohiia: osoblyvosti funktsionuvannia $v$ suchasnomu movnomu prostori. PhD Thesis Abstract. Lviv, 2016.

Kuz, H. "Vplyv khrystyianskoho svitohliadu na komponentnyi sklad ta funktsii vyhukovykh frazeolohizmiv". Bibliia i kultura, iss. 1, 2000, pp. 233-7.

Matskiv, Petro. Kontseptosfera Boh v ukrainskomu movnomu prostori. Kyiv - Drohobych: Kolo, 2007.

Moisiienko, Anatolii. "Aktualizatsiia frazeolohichnykh odynyts u khudozhnomu teksti". Ukrainska leksykohrafiia $v$ zahalnoslovianskomu konteksti: teoriia, praktyka, typolohiia: materialy Mizhnarodnoi naukovoi konferentsii, prysviachenoi pamiati prof. L. H. Skrypnyk. Kyiv: Vydavnychyi dim Dmytra Buraho, 2011, pp. 115-21.

Mokienko, Valerij. Slavjanskaja frazeologija. Moskva: Vysshaja shkola, 1989.

Nimchuk, Vasyl. "Khrystyianstvo y ukrainska mova”. Ukrainska mova, no. 1, 2001, c. 11-30.

Ohiienko, Ivan. Ukrainske monashestvo. Kyiv: Nasha kultura, 2002.

Osinchuk, Yurii. Istoriia ukrainskoi bohosluzhbovo-obriadovoi leksyky. Kyiv: Vydavnychyi dim Dmytra Buraho, 2009.

Piddoubna Nataliia. The formation of the nomenclature of religious buildings names in the Ukrainian language. PhD Thesis Abstract. Kharkiv, 2000.

Potebnja, Oleksandr. Iz lekcij po teorii slovesnosti. Basnja. Poslovica. Pogovorka. Har'kov: Gosizdat Ukrainy, 1930.

Selivanova, Olena. Narysy z ukrainskoi frazeolohii (psykholinhvistychnyi ta etnokulturnyi aspekty). Kyiv - Cherkasy: Brama, 2004.

Skab, Mariia, Skab, Marian. "Bibliini frazeolohizmy yak obiekt movnoi hry v suchasnii ukrainskii literaturi". Scientific notes of Taurida National V. I. Vernadsky University, series "Philology. Social Communications", vol. 25 (64), no 2 (1), 2012, pp. 232-7.

Skab, Mariia. "Frazeolohizmy $\mathrm{z}$ relihiinym komponentom v ukrainskykh slovnykakh". Ukrainska leksykohrafiia $\mathrm{v}$ zahalnoslovianskomu konteksti: teoriia, praktyka, typolohiia: materialy Mizhnarodnoi naukovoi konferentsii, prysviachenoi pamiati prof. L. H. Skrypnyk. Kyiv: Vydavnychyi dim Dmytra Buraho, 2011, pp. 107-14.

Skrypnyk, Larysa. Frazeolohiia ukrainskoi movy. Kyiv: Naukova dumka, 1973.

Slonov, V. "Bibliia na urokakh ukrainskoi movy". Urok ukrainskoi, no 2, 2002, pp. 37-42.

Sulyma, Vira. Bibliia i ukrainska literatura. Kyiv: Osvita, 1998.

Telija, Veronika. Tipy jazykovyh znachenij. Svjazannoe znachenie slova v jazyke. Moskva: Nauka, 1981.

Tkach, L., Shepetiuk, I. "Ievanheliini motyvy v ukrainskii narodnii frazeolohii ta v dyskursi ukrainskoi memuarystyky pochatku KhKh st. (za shchodennykamy S. Yefremova)". Scientific Herald Yuriy Fedkovych Chernivtsi National University. Series: Slovianska filolohiia, iss. 87, 2000, pp. 109-127.

Uzhchenko, Viktor, Uzhchenko, Dmytro. Frazeolohiia suchasnoi ukrainskoi movy. Kyiv: Znannia, 2007.

Tzareva, Irina. "Ritual background of phraseologizms of North Ukrainian and East Slobozhanschina dialects”. Volyn-Zhytomyrshchyna, no 22(II), 2010, pp. 289-95. 
Tsyperdiuk, Oksana. "Bibliini aliuzii v poetychnykh tekstakh Vasylia Herasymiuka”. Scientific Herald Yuriy Fedkovych Chernivtsi National University. Series: Romano-Slavonic Discourse, iss. 772, 2016, pp. 110-5.

Стаття надійшла до редколегії 02.03.2019 